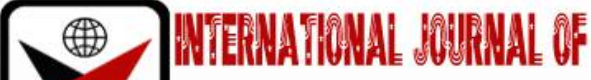

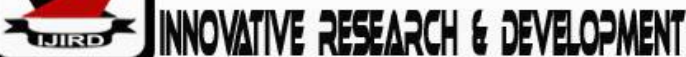

ISSN 2278 - 0211 (Online)

\section{Entrepreneurship, Globalization, Youth's Restiveness and National Development}

Dr. Esther A. Olanrewaju Sanya
Lecturer, Department of Management and Accounting,
Lead City University, Nigeria
Godday Chukudi Nwoko
Principal Lecturer, Department of Office Technology and Management,
Auchi Polytechnic, Nigeria

\begin{abstract}
:
This paper looks at the impact of entrepreneurship on youth's restiveness and its importance to national development. The term entrepreneurship and entrepreneurs are often seen as innovators and agents of development and change within the society. Entrepreneurship is also considered to be a significant tool needed for shaping economic growth and the development of any nation through globalization. Reason is because entrepreneurship assists in generating employment opportunities thereby depopulating the unemployment market. This ample step made a positive impact on innovation and the well-being of the youths within the community where such entrepreneurial venture is cited (Acs, $Z$. J.; Desai, S. \& Hessels, J., 2008). Shaw (2004) postulated that entrepreneurship is an attitude, a way of thinking and learning. It is a state of mind, insightful and innovative mentality rather than business administration. Succinctly, government of any nation must put constructive measures in place to encourage entrepreneurship directed towards youth empowerment which will cause reduction in youth's level of restiveness. This singular step based on the following premise:

Peaceful coexistence

Societal coercion

Communal cooperation and

Economic growth and stability will on the long run lead to National development. Youth empowerment is a process whereby young adults and children are encouraged to take charge of their lives. This can be achieved when youths interact with other culture which is made possible by interacting with other cultures and ideas through ICT which is brought about by globalization. They do this by addressing their situation and take necessary action capable of improving their access to resources that can transform consciousness through their beliefs, value system, way of life and attitudes. Youth empowerment is an attitudinal, structural and cultural process whereby young people gain the ability, authority and agency to make decisions and implement change in their own lives and the lives of other people Minniti, M.; Moren, L. (2010).
\end{abstract}

Keywords: Entrepreneurship, entrepreneur, globalization, youth's restiveness, national development

\section{Background to the study}

The potentials and benefits of entrepreneurship is a determining factor for development of any nation, especially its youths. This is because they are the young generation, able bodied, energetic as well as sellable in the employment market. Hence, the government of such country must strive to put in place policies that will embrace entrepreneurship in order to assist them to be self-reliant. An entrepreneur could be defined as the founder of the enterprise who identifies opportunities, assembles skilled manpower and necessary resources for the operation of the enterprise, attracts persons and financial Institutions and takes psychological responsibility for managing the enterprise successfully. The word 'Entrepreneur' is derived from the French word "Entreprendre" which means, "to undertake." Entrepreneurs are actionoriented highly motivated individuals who take risks to achieve goals. An entrepreneur is an innovator of new combination in the field of production to generate employment opportunities for others.

\subsection{Development of Entrepreneurship in Nigeria}

Entrepreneurial forces are relatively strong in this country, as the lack of jobs and a rise in poverty level leave few other options of entrepreneurship for the Nigerian people. Although difficult due to a lack of resources, there are nonprofit organizations such as the Fate Foundation in Nigeria that are dedicated to promoting entrepreneurship. Apart from the information about Nigeria that is so widespread and often negative, there appears to be recognition of the critical role and place of technology in the development and advancement of the nation. In the past few years, there have been the 
startups of internet cafes, new Internet Service Providers, computers in some schools, and connectivity hubs that provide access to information at high speeds. The Nigerian government has created and adopted policies promoting the use of technology in education. The Nigerian Economic Policy 1999-2003, is a comprehensive compendium of President Obasanjo's policies and guiding principles for the nation.

The policy states: "Government will provide affordable quality education for all Nigerians, the Universal Basic Education and mass Adult Literacy programmes will be pursued in earnest" and in particular, "Government will create incentives to expand access to information and communications technology which will facilitate leap-froging in order to short-circuit the longer span of development." The policy even recommends partnerships with national and international agencies including the United Nations Transfer of Knowledge through Expatriate Nationals programme or TOKTEN as it is commonly known. However, an important distinction between developed and developing nations often lies in the wide disparity between policy pronouncements and policy implementation. Often, signs of this disparity are found in the extent that policies are clear and measurable and that application is consistent. Often developing nations adopt excellent policies and guidelines that could, if well implemented, change the futures of their citizens but alas, they are very often not followed through. If Nigeria follows-through with its new laws guiding entrepreneurship, education and technology with action and implementation, and the people of Nigeria attain their educational goals and professional potential with the tools available to the world today we will witness the transformation of what is presently a Third world giant (or toothless bulldog) into an Emerging economic giant. These are attainable goals.

- Entrepreneurship activity in Nigeria is primarily based on necessity.

- The majority of entrepreneurs in the country are operating in Lagos, the former capital of the country.

- Nigeria's economic decline since the 1980's has created a hostile environment that is unfavorable to entrepreneurial success.

- The Nigerian infrastructure limits entrepreneurial effectiveness and is a barrier to success.

- The high cost of doing business in Nigeria, such as the lack of adequate electricity and basic needs by a large amount of the population stifle entrepreneurial activity.

- Getting venture capital to finance entrepreneurial endeavor in Nigeria is very difficult because of the political and economic instability.

- The policies of the Nigerian government are a barrier to the success of large-scale entrepreneurial success for many Nigerians. The government is plagued by corruption and greed. The government systematically ignores laws that are already in place to promote free enterprise.

- The lack of enforcement of Nigerian patent laws discourages entrepreneurs from commercializing their ideas and inventions.

- The constant political turmoil in the country greatly limits foreign investors who would be willing to provide resources for entrepreneurship in the country, which is very rich in natural resources.

- Political and social movements strongly affect the level of entrepreneurial activity in Nigeria. Religious intolerance and ethnic warfare limit country progress in some areas of the country.

- Female entrepreneurs in Nigeria are often underestimated and overlooked.

- Female entrepreneurs in Nigeria are often hindered because of cultural barriers such as male/female role definitions that label women inherently inferior to men.

- $\quad$ Nigeria has the 2nd largest GDP in Africa; South Africa has the largest.

- The Ibo ethnic group in Nigeria is recognized internationally for its culture of entrepreneurship.

- The majority of entrepreneurs in the country are operating in the capital city of Abuja.

- Control own life, to be my own boss, freedom to adapt personal approach to work and attain family security are some of the reasons Nigerians engage in entrepreneurial activity.

- The Nigerian government has a program in place that promotes exports from Nigeria to other countries, which can be helpful for entrepreneurs looking to do business in Europe or the United States.

- Lower taxes and increased price ceilings have increased the incentives to entrepreneurs in the country.

- Nigeria is progressively trying to incorporate modern technology into its country.

- $\quad$ Nigeria is trying to actively promoting technology in its educational system with the use of the internet.

- Although there are a lot of barriers, entrepreneurship in Nigeria is necessary for the country to become a developed nation.

Source: http://www.internationalentrepreneurship.com/africa/nigeria/

\subsection{What is the meaning of Entrepreneurship?}

Entrepreneurship as an engine of innovation and job creation is a mechanism for changing the distribution of wealth and well-being in society. Entrepreneurship is the process of identifying and developing economic and social opportunities through the efforts of individuals and organizations, which can result in starting and building new businesses, either as independent enterprises or within incumbent organizations. Individuals discover opportunities in markets and organizations; how these opportunities are pursued results in different forms of entrepreneurship, such as independent start-ups, licensing activity, corporate ventures and spin-offs, and nonprofits. Because entrepreneurship is inexorably linked to institutional processes and organizational forms, the discipline of sociology is central to the development of entrepreneurship research. In the early 21st century, considerable resources have been devoted to the study of entrepreneurship, and this momentum points to an increasing variety of research perspectives. 
The threads of coherence to this bibliographic selection stem from a Weberian view of institutions. Just as Max Weber viewed society as composed of various institutional orders and organizational forms, the field of entrepreneurship research is composed of interdisciplinary perspectives drawing from the social sciences. Although this article takes a sociological view, it also includes selected works of authors in the sister social, management, and financial sciences that borrow sociological concepts or that flesh out the relevance of the sociology of entrepreneurship. This border crossing is more prevalent with the classic scholars because they are a relatively fuzzy set. Finally, in keeping with the good scholarly practice of elucidating the roots of ideas, this bibliography strives to include the classics and the initial theoretical and empirical formulations and their key elaborations, focusing more on the mechanisms that explain entrepreneurship. (Saxenian, AnnaLee. (1995); Sørensen, Jesper B. (2007); Thébaud, S. (2013).

\subsection{General Overviews}

The field of entrepreneurship does not have its own conceptual framework that explains and predicts a set of empirical phenomena. This has led scholars to produce a variety of partial reviews and programmatic statements of issues, debates, and approaches to the study of entrepreneurship. Thornton 1999 classifies entrepreneurship research into supply- and demand-side perspectives, conceptualizing a duality of the availability of suitable individuals to fulfill entrepreneurial activity (based on factors such as psychological traits), and the structural conditions that influence the number and nature of entrepreneurial roles that need to be filled. Swedberg 2000 highlights the importance of the classics as a foundation for future research. The ten-chapter edited volume. Ruef and Lounsbury 2007 focuses on a variety of phenomena-based research on the sociology of entrepreneurship. Sorenson and Stuart 2008 suggest that scholars from different disciplines should participate in research to explain phenomena-based research. Carroll and Khessina 2005 argue for an ecological approach to the study of entrepreneurship. Aldrich 2011 expands on the ecological perspective by presenting a collection of essays on the evolutionary approach to entrepreneurship. Entrepreneurship is the act of creating a business or businesses while building and scaling it to generate a profit. However, as a basic entrepreneurship definition, it's a bit limiting. The more modern entrepreneurship definition is also about transforming the world by solving big problems. Like initiating social change, creating an innovative product or presenting a new life-changing solution. What the entrepreneurship definition does not tell you is that entrepreneurship is what people do to take their career and dreams into their hands and lead it in the direction of their own choice. It's about building a life on your own terms. No bosses. No restricting schedules. And no one is holding you back. Entrepreneurs are able to take the first step into making the world a better place, for everyone in it.

\section{List of Some Nigerian Entrpreneurs}

Nigeria being a developing country in West Africa has opened lots of opportunities to its citizens to start, grow and earn money in their entrepreneurship journey. This list is focusing on just 20 famous entrepreneurs in Nigeria. Since we are talking about entrepreneurs, this list is restricted to entrepreneurs only. Politicians and individuals whose source of wealth cannot be traced are excluded from this list. The list contains their name and the industry in which they are famous in as a result of their success. The criteria for coming up with this list as it was compiled based on the following criteria:

- $\quad$ By the worth of their shares held in quoted companies.

- The impact of their companies on the Nigerian economy

- The market value of their company's brand

- The number of companies they own and its assumed value

- The size and market share of their companies

So instead of boring you with their success stories; we have extracted the vital lessons learned from the life of these famous entrepreneurs. If you are ready to learn, below is a list of some of the Nigerian famous entrepreneurs and top richest people in Nigeria.

Nigerian's Top 20 Famous Entrepreneurs in Nigeria 2015 (in Alphabetical order) 


\begin{tabular}{|l|l|}
\hline \multicolumn{2}{|c|}{ Name Company Name (Industry) } \\
\hline Alhaji Aliko Dangote & Dangote Group, (Manufacturing, oil \& gas,) \\
Alhaji Sayyu Dantata & MRS Group (Oil \& gas, construction) \\
Chief Ade Ojo & Elizade Motors Nig LTD (Auto retailing) \\
Chief Molade Okoya Thomas & Ibeto Group (Trading, manufacturing, oil \& gas) \\
Cosmos Maduka & Chairman CFAO Nig and other six French companies (Automobiles) \\
Dele Fajemirokun & Coscharis Group (Automobile, manufacturing) \\
Femi Otedola & Chaiman Aiico Insurance, Xerox Nigeria, Chicken Republic, Kings Guards \\
Fola Adeola & (Insurance, Security, Technology, Food retailing) \\
Hakeem Bello Osagie & Forte Oil and Gas (Oil \& gas) \\
Jim Ovia & GTBank (Banking) \\
Jimoh Ibrahim & Etisalat Nigeria (Telecom) \\
Leo Stan Ekeh & Zenith Bank, Visafone (Banking, Telecom) \\
Mike Adenuga & Nicon Insurance, Global Fleet (Insurance, transportation, oil \& gas) \\
Oba Otudeko & Zinox (Computer, technology) \\
Orji Uzor Kalu & Conoil, Globacom (Oil \& gas, Banking, Telecom) \\
Pascal Dozie & Honeywell Group Nigeria, Pivotal Engineering, Airtel (Manufacturing, oil \& \\
Prince Samuel Adedoyin & gas, telecom) \\
Tony Ezenna & Slok Group (Aviation, Shipping, publishing, manufacturing) \\
Umaru Abdul Mutallab & MTN Nigeria, Diamond Bank (Banking, Telecom) \\
Vincent Amaechi Obianodo & Doyin Group (manufacturing, pharmaceuticals) \\
& Orange Group (Pharmaceutical, oil \& gas) \\
& former Chairman First Bank Plc, Mutallab Group \\
& Young Shall Grow Motors, RockView Hotels (Transportation, hotels) \\
\hline
\end{tabular}

Table 1: Nigerian's Top 20 Famous Entrepreneurs In Nigeria 2015 (In Alphabetical Order)

Despite the harsh terrain and business challenges involved with starting a business in Nigeria; the successful entrepreneurs listed above held their ground and fought their way to the top. In a country with a population of over 170 million inhabitants and millions of businesses; these 20 entrepreneurs diligently carved their names in the sands of time by taking advantage of the fastest growing business opportunities in Nigeria among many African businesses. The famous entrepreneurs in Nigeria are dogged in guts. They are strong willed and unrelenting. Success is not an option to these set of individuals in fact it's a must. These individuals refuse to be held down by circumstance; instead, they reached out for their inner strength and went for success. Above all, these entrepreneurs don't take no for an answer; they basically say no to giving up and that was why they succeed.

\section{Some Foreign Based Entrepreneurs}

Walt Disney cofounded the Walt Disney Company one of the leading motion picture studios. He was also the visionary of theme parks like Disneyland and Walt Disney World. His brand started with the creation of the Mickey Mouse character and eventually expanded to include characters like Snow White, Cinderella and more. As an entrepreneur, he had to overcome adversity with challenges such as people stealing his work, commercial failures and more. However, he kept pushing through staying committed to his vision.

Mark Zuckerberg created several products before building Facebook. He created an instant messaging tool that his father used in his dentistry practice to communicate with his receptionist. Zuckerberg also created music software that Microsoft and AOL were interested in buying even though he was only a teenager. Within the year he first founded Facebook, he had already had 1 million users. Today, Mark Zuckerberg has a net worth of \$68.3 billion.

Altimese Nichol What's the entrepreneur meaning? Altimese Nichole, Founder of Nichole Nicole shares, "Many are excited to become an entrepreneur but get discouraged when reality hits. Entrepreneurship means staying committed to your goals beyond your feelings of excitement. Stay the course and keep your "why" in mind."

Christopher Molaro's entrepreneurship definition What's the meaning of entrepreneurship? Founder and CEO of Neuro Flow shares "Entrepreneurship means being the one that is willing to take a leap, work hard enough to sacrifice everything else around you, all in the name of solving problems because no one else is capable or possesses the desire."

The entrepreneur meaning is a bit different for Jolijt Tamanaha, Director of Marketing and Finance of Fresh Prints, who shares "Entrepreneurs make their way down a never-ending list of problems with grit, passion, and energy. While intense, being an entrepreneur means you get to live life learning an incredible amount and maximize your impact on the world because you have to tackle the hardest problems."

What is the entrepreneur meaning for Nicole Faith, Founder of 10 Carat Creations? Here's how she breaks it down, "Being an entrepreneur means having a plan and vision but still succeeding or trying to succeed when the plan falls apart and you're left with only your vision. It also means knowing when to give up, especially if your idea isn't working due to forces outside of yourself."

What's the entrepreneur meaning? According to James Sandoval, Founder and CEO of Measure Match, says, "Being an entrepreneur means diving headlong into a [likely very risky] venture of your own making, working hard, long hours, often alone, to carve out a path to success and never, ever giving up."

Mike Kim, co-founder and COO of KPOP Foods, shares what the entrepreneur meaning is really all about. He shares, "Entrepreneurship is not for the faint hearted. I am a US Army veteran. I have been in combat and I have endured 
many difficult situations. However, I can honestly say starting a company has been just as challenging, albeit in different ways. While no one's life may be in imminent danger, the battles you face on your entrepreneurial journey can last years with no repose. Creating a successful business requires massive amounts of action, perseverance, and conviction. If you understand this and choose to proceed, you'll find the experience rich in rewards."

\subsection{Importance of Entrepreneurship to National Development}

What is entrepreneurship really about? And why's it so important? An entrepreneur is the person who sees a problem in the world and immediately focuses on creating the solution. They're the leaders that strike out on their own to improve society. Whether they're creating jobs or a new product, they constantly take action to ensure world progress. In the process of understanding what is entrepreneurship, let's look at why entrepreneurs are important in society. Entrepreneurship as an engine of innovation and job creation is a mechanism for changing the distribution of wealth and well-being in society. Entrepreneurship is the process of identifying and developing economic and social opportunities through the efforts of individuals and organizations, which can result in starting and building new businesses, either as independent enterprises or within incumbent organizations. Individuals discover opportunities in markets and organizations; how these opportunities are pursued results in different forms of entrepreneurship, such as independent start-ups.

\subsection{Concept of Globalization}

Globalization has been defined as westernization. Therefore, globalization is regarded as a particular type of universalization, one in which the social structures of modernity (capitalism, industrialism, rationalism, urbanism etc.) are spread the world over, thereby destroying pre-existent cultures and local self-determination in the process. Globalization in this perspective is often interpreted as neo-colonization and Americanization as Westernization and an imperialism of McDonald's and CNN (1998). These critics, when they talk about globalization, see it as a hegemonic discourse, an ideology of supposed progress that masks far-reaching destruction and subordination. It is one thing to assert that globalization, internationalization and westernization have had interconnections and quite another to equate these phenomena. After all, the notion of globalization is not new, but the concept and its far-reaching implications will always have great influence on the industrial, political, economic as well as social relations in any system/country. In addition, the ingredients of any economy involved in globalization such as standardization, industrialization, marketization and other norms adherence serve both as variables and at the same time create a chance for mutual interdependence. Globalization has also brought about cultural diffusion. This is because; man is naturally an imitative creature. When men interact, communicate and dwell among themselves they tend to copy ideas that look good to them from others. It is these facts that actually render human culture unavoidably contagious. (Anyanwu, C. N. 1999).

\subsubsection{What about Youth's Restiveness?}

Jaja, (2010) in his own submission asserts that, the internet is the turbo charger that aided globalization to boost all over the world. This is because it has helped by radically facilitating, outsourcing, management, regulating, logistics, just-in-time controlling, business-to-business and business-to-consumers contacts, and has succeeded in a revolutionized manner that we could never have imagined until recently that of the internationalization of production. The three major components of the internet are that it contains the biggest, richest and widest range of information dissemination source for the whole world. Secondly, it avails instant communication interactive mechanism for all. Knowledge is power, and information is the key to knowledge. The data information transmission, knowledge acquisition, dissemination and creation of a value chain which is made possible through ICT. Therefore, developing countries need not recreate costly knowledge; they already have the advantages of acquiring and adapting knowledge available in the richer countries (Jaja, 2010). That most Nigerian youths now hooks to the weird western cultures which they are exposed to, through the ICT via various media is an issue that points to the negative effects of globalization. This had in effect de-alienated them from the norms and values of their heritage cultures and dragged them off their traditional foundations. Whereas the Bible says "If the foundation be destroyed, what could the righteous do"? (Psalm11:3). The Bible goes further in Matthew 5:13 that; "Ye are the salt of the earth; but if the salt has lost its savour, wherewith shall it be salted"? It is thenceforth good for nothing, but to be cast out, and trodden under the foot of men. These are questions for everyone who believes he/she is a Nigerian and it poses answerability to all.

\section{Characteristics of Youth's Restiveness}

\subsection{Youthful Exuberance}

When we look at the dressing mode of our youths it is something else; here the euphoria affects both male and the female within our society. The male goes about with his trousers down, half his backside (buttocks) and it no longer rests on the waist with proper belting-up style. The underpants are exposed to all who care or do not wish to see, an attitude or dressing mode that is absurd, unhealthy and un-African in all ramification. These the boys see as old fashioned and call their newly found dressing code "sagging". This we were made to understand is a way to keep prisoners alive by the warders who had seen prisoners hanging themselves, in order that they do not hang themselves with their belts due to frustrations or the disappointment they exposed their family to because of the criminality they engaged themselves into, they usually seize their belts. This does not stop with boys alone in the craze, the girls and young ladies too are not left out of this crazy dressing. Many of them go about half or almost naked with their breasts popping out from the skimpy tops, 
thighs, arm-pits and everywhere is there for all to view with impunity all in the name of fashion and exposition to new cultures that does not conform with African culture curtsey Globalization.

\subsubsection{Drug and Drug Abuse}

The negative effects of globalization brought about the exposition of Nigerians to hard drugs consumption. These include Indian hemp, cocaine, cannabis, marijuana, etc. Many young men and women who are talented have been ruined because they have involved themselves in smoking, carrying and or selling these hard drugs and the long arm of the law has caught up with them. They could have been stars in their own right but due to influences of friends and craze for fast money had ended up in jail instead of being at the top in their chosen career.

\subsubsection{Criminal, Criminalities and the Vices}

The aftermath effect of ICT and exposition of Nigerian youths to drugs, expensive life style has toughened them to the extent that so many of them are exposed to criminalities. They have turned to robbers as they have been taught the art of operating arms and ammunitions to rob on the highways. To many parents of these youths they are in the safe confines of their hall of residence in their respective colleges and universities. Globalization with the aid of ICT has also exposed them to promiscuity, phonograph, masturbation, lesbianism, homosexuals etc. All these are cutesy of accessibility to the internet and the cable channels which is a free for all electronic gadgets readily available in all homes nowadays. Some parents do not oversee what their children watch on the television sets, on the internet and they also fail to create time to supervise their children and wards. This also helped the increase of street children/ youths as many have absconded from home to join bad gang from where they are sent to jail and are no longer wanted at home.

\subsubsection{Advance Free Fraudism}

When we look at the adverse effects of globalization, we discover that so many Nigerians have been exposed and involved in the proliferation of cybercrimes. This has been given different accolades like 419, Yahoo Boys, Yahoo Plus, and Yahoo-Yahoo and so on. Many of these youths who do not have a mind of their own and are not Godly minded are usually involved because they are either too weak to resist the goodies attached to fraud or they are criminally minded. To crown it all, the issue of unemployment ravaging the whole country also played a major role in initiating these youths into frauds all in the name of seeking after survival. Many of these fraudsters had through this means ripped many women and men white or black of their life possessions, belongings and or savings by pretending to be ready to marry them, rather they are out to scrape and clear their wealth. Some of their victims take it as their cross and encourage themselves to be more careful in future, while those who can pursue them report their plight to the police and INTERPOL sometimes pick them up and they end up in jail. This leads to the thwarting of the plans of their parents and guardians on their lives.

\subsection{HIV/Aids and other Deadly Diseases}

The present trend and spread of HIV/AIDS and other related deadly diseases are being contacted through sexual promiscuity of some youths in Nigeria. This scourge had become a social, economic and financial catastrophe in the sense that millions of Nigerians, young men and women, youths, girls, pregnant women are infected with the HIV virus. It is seen as one of the products of globalization and is considered as one of the greatest global health hazards as well as the highest developmental challenge of our time in this $21^{\text {st }}$ Century. This scourge affects anyone and all strata of the populace and cannot be compared to other commercial diseases. Therefore, at a special summit held in Abuja, Nigeria from April 26-27, 2001, Heads of State and Government of the Organization of African Unity (OAU) met to review and critically assess the HIV/AIDS challenges facing Africa. They declared, 'Aids as a State of Emergency on the continent", and vowed to make the battle against HIV/AIDS the "Highest priority in their respective national development plans".

Also, the United Nations Secretary General Kofi Annan declared the HIV/AIDS situation in Africa as catastrophic and called for a special session of the General Assembly (UNGASS) in New York, which was held from June 25-27, 2001. The UNGASS addressed these issues and created the Global Fund for Aids and Health, to finance intensified activities around the world (particularly in Africa), in attempts to curtail the continuing and accelerated spread of the epidemic (UNGASS, 2001). According to Obinna (2001), Nigeria is one of the worst hit by HIV/AIDS on the African continent. It is estimated that about 3.1 million Nigerians are infected with the disease, meaning that Nigerians has the second largest number of people living with HIV/AIDS in sub-Saharan Africa and the highest in West Africa.

\subsection{Human/Child Trafficking}

The phenomenon, globalization has caused a negative effect on Nigerians and this has affected who engage in the business of human/child trafficking. Some men, ladies and children are being transported from Nigeria to other neighbouring countries like USA, UK, Italy, Germany etc. in order to seek for greener pastures. Some of these people went to work as maids, houseboys, commercial sex workers and in effect, are infected with this deadly disease and this they spread to Nigeria when they came back or repatriated back home. Trafficking in persons, which the International Labour Organization (ILO, 2001:47) describes as "the underside of globalization", is one of the greatest human rights challenges of our time. Some of their victims are sweet-tongued and lured abroad and their mission there is made known to them only when they get there, where they are forced into sexual activities for money. They do engage in this nefarious and deadly trade sometimes without using condoms because of their hurry to get rich quick and in most cases, their benefactors borrow the money to transport them to their destinations and they have to work very hard to pay back the loans they obtained forcefully. 


\section{Conclusion and Recommendation}

This paper has attempted to capture the place of Entrepreneurship and effects of globalization as well as curtailing youth's restiveness in Nigeria. Looking at the present situation, it is a fact that does not need a research work to convince anyone that the National Development of any nation rests on the youths who are leaders of tomorrow. Hence, adequate exposure of youths to positive internalization of global trends and entrepreneurial awareness. As a result, achievement of their potentials as well as exposure to both local and International best practices that eschews violence, and in effect become a responsible, committed and patriotic citizens of the Nation.

\section{References}

i. Minniti, M.; Moren, L. (2010). "Entrepreneurial types and economic growth". Journal of Business Venturing. 25 (3): 305-314. doi:10.1016/j.jbusvent.2008.10.002.

ii. Source: http://www.internationalentrepreneurship.com/africa/nigeria/

iii. Dunlop, J.T. (1972): Industrial Relations System, New York, Henby Holt \& Co. 1972 pg. 12.

iv. Eregha, P.B. and Irughe, I.R (2009): Oil Induced Environmental Degradation in Nigerias Niger Delta: The Multiplier Effects. Journal of Sustainable Development in Africa 11 (4).

v. Houston Institute for Culture: "Globalization" Available at http/www/Houston culture org/global/index html).

vi. Houston Institute for Culture "Americanization" [Available at http://www.houstonculture.org/global/amer.html], (Accessed 15.03.2016).

vii. Hurell and Woods, (1999): Inequality, Globalization and World Politics. www.amazon.com $>$ Books $>$ New, Used \& Rental Textbooks.

viii. Anyanwu, C. N. (1999): Elements of Comparative Studies in Adult Education. Gabester Educational Publishers, Ibadan. ISBN 978-2817-18-X.

ix. Ruef, M. (2010): The Entrepreneurial Group: Social Identities, Relations, and Collective Action. Princeton University Press Princeton, NJ, 2010.

x. Ruef, M; Michael (2007): Lounsbury, eds. The Sociology of Entrepreneur ship. Elsevier New York, 2007.

xi. Saxenian, AnnaLee. (1995) Regional Advantage: Culture and Competition in Silicon Valley and Route 128. Harvard University Press Cambridge, MA, 1995.

xii. Sørensen, Jesper B. (2007): "Bureaucracy and Entrepreneurship: Workplace Effects on Entrepreneurial Entry." Administrative Science Quarterly, v. 52 (2007).

xiii. Sørensen, Jesper B. (2007): "Closure and Exposure: Mechanisms in the Intergenerational Transmission of SelfEmployment." Research in the Sociology of Organizations, v. 25 (2007).

xiv. Thébaud, S. (2013). Entrepreneurship. In V. Smith, Sociology of work: an encyclopedia. Thousand Oaks, CA: Sage Publications. Retrieved from https://search. Credo reference. com/content/topic/entrepreneurship

xv. Source:http://www.internationalentrepreneurship.com/africa/nigeria/

xvi. Houston Institute for Culture: “Globalization” Available at htpp/www/Houston culture org/global/index html).

xvii. Hurell and Woods, (2003): Inequality, Globalization and World Politics. www.amazon.com $>$ Books $>$ New, Used \& Rental Textbooks.

xviii. Hyman, Richard (1975): Industrial Relations: A Marxist Introduction. Macmillan

xix. ILO (2001): Stopping Forced Labour: Global Report under the follow-up to the ILO Declaration on Fundamental Principles and Rights at Work, International Labour Conference, 89 ${ }^{\text {th }}$ Session 2001, report 18.

Xx. IMF (1997): "Globalization, Opportunities and Challenges" World Economic Outlook, May.

xxi. Jaja, J.M. (2010): “Globalization or Americanization: Implications for Sub-Saharan Africa”, in Deng, K.G.(ed) Globalization - Today, Tomorrow, Croatia: Sciyo. 